\title{
Cambodian National Education Policy: Global Wants or/and Local Needs?
}

\author{
Kelly Crowley-Thorogood (University of Western Ontario)
}

\begin{abstract}
This paper will explore the problems associated with educational reconstruction in postconflict Cambodia using a globalization theoretical perspective. The main questions to be addressed are: to what extent is globalization influencing education policy development in post-conflict Cambodia? and how have multinational financial agencies influenced the creation and adoption of national education policies in post-conflict Cambodian society? This paper will offer an introduction to globalization theory and provide a policy analysis of recent Cambodian and multinational policy documents and directives. The policy analysis will demonstrate that the agendas of several major multinational organizations have influenced educational policy in Cambodia due to the country's continued dependence on foreign monetary assistance for development.

Résumé

Cet article cherche à explorer, par le biais d'une perspective théorique de globalisation, les problèmes issus de la reconstruction du système éducatif après le conflit cambodgien. Les questions principales sont les suivantes : jusqu'à quel point la globalisation influence-t-elle le développement des politiques éducatives et comment les agences financières multinationales ont-elles conditionnées la création et l'adoption de politiques éducatives nationales dans la société cambodgienne d'après guerre ? Cet article introduira la théorie de globalisation et analysera les documents et les directives politiques du Cambodge contemporain. L'analyse politique démontrera que les agendas de plusieurs organisations multinationales ont en effet influencé la politique éducative du Cambodge car le pays est continuellement dépendant financièrement de l’étranger.
\end{abstract}

\section{GLOBALIZATION THEORY: A BRIEF INTRODUCTION}

Globalization is a much discussed and defined concept. This paper utilizes the view that globalization is a process that influences political, economic, cultural, and geographic realities in all nations, regions, and districts. The process of globalization has increased as the flow of capital, ideas, organizations and people has taken on a distinctly global form (Moghadam, 2005). Globalization theory holds that current trends in the economic, political, and cultural spheres of society are creating fundamental changes in forms of governance and social life. Globalization theory see these trends as creating an increasing connectivity between all nation-states and this connectivity is leading to new roles and positions for national governments. Globalization as a process is cyclical and involves economic and political life in a world system of nation-states and multinational organizations. Due to the increased economic connectivity 
associated with globalization, multinational financial organizations have become much more active in national political and social affairs, including education.

In Cambodia, two of the largest financial contributors to education reform are the World Bank (WB) and Asian Development Bank (ADB). Each organization has important policy directives in place for the implementation and management of Cambodian education reform. These directives will be briefly described below.

\section{WORLD BANK AND ASIAN DEVELOPMENT BANK EDUCATION POLICY DIRECTIVES}

The World Bank is the largest multinational financial organization, in terms of funding to all sectors, in Cambodia. There are several key World Bank policy directives that directly address Cambodian national education policy. The Education Sector Support Project (ESSP), implemented in 2005, is the most significant World Bank policy directive as it sets out the organization's vision for education in Cambodia for five years (WB, 2005a). It is the overarching document of the World Bank for education reform. In contrast, the Country Assistance Strategy (CAS) is a directive that lays out the objectives and development agenda for all sectors in Cambodia, of which education is a part (WB, 2005b).

The primary policy directive from the ADB, which focuses specifically on Cambodian education, is the Second Education Sector Development Program (ESDP II) (ADB, 2004a). The ESPD II consists of three different but connected components. There is a program loan for $\$ 20$ million (USD); a project loan for $\$ 25$ million (USD); and a technical assistance of $\$ 500,000$ (USD) (ADB, 2004a). Therefore, the total financial contribution from the ADB in this project is $\$ 45,500,000$ USD. This money was to be disbursed over a period of three years, 2005 to 2008. In comparison, the World Bank provided \$28 million (USD) to education over a period of five years (2005-2010). However, overall the World Bank provided more overall funding to Cambodia to help with reforms in multiple sectors of society.

The second Asian Development Bank policy directive that has had an impact on the educational agenda in Cambodia is the Country Operations Business Plan (COBP) (ADB, 2008). The COBP was created in conjunction with the country strategy and program and is very much like the World Bank's CAS. What is particularly interesting about the COBP is that it lists the education sector as a key target for the economic and business development in the country. The education sector is listed alongside the agriculture and natural resource sector, financial sector, power sector, transport sector, water supply and sanitation sector, and private sector development as the keys to expanding business in Cambodia.

The financial contribution of the ADB is substantial in relation to the World Bank, as demonstrated above. However, in reading through the 
documents, it appears that despite the disparity in financial contributions to educational reform, the World Bank leads the development agenda in Cambodia, as a much larger and politically powerful organization internationally. There are many references throughout the ADB policy directives to World Bank objectives and ideologies. However, despite many similarities, each organization has a clear and distinct agenda within Cambodia. Yet, as shall be discussed below, the underlying ideologies may be the same but the means to getting there are different for each organization.

\section{THE NATIONAL EDUCATION POLICIES OF THE ROYAL GOVERNMENT OF CAMBODIA}

The Royal Government of Cambodia (RGoC) officially joined the global movement for "Education for All" in 2003. The Royal Government of Cambodia set out nine domestic Millennium Development Goals to align with those promoted by the United Nations (MoEYS, 2003). One of these goals was the achievement of universal primary education by 2015 . The process of achieving these goals involve long-term and medium term policies.

The $3^{\text {rd }}$ Education Strategic Plan (ESP) is the clearest national policy for education reform in Cambodia (MoEYS, 2005a). The latest ESP was adopted in December 2005 and is set to run a course of five years. The $3^{\text {rd }}$ ESP lays out three main policies for education reform in Cambodia. These are: equitable access to education services; quality and efficiency of education services; and institutional development and capacity building for decentralization (MoEYS, 2005a). What is interesting about these policies is that they tend to echo multinational financial agendas.

A second key policy is the Cambodian Education Sector Support Program 2006-2010, named after the World Bank policy directive that was used to create the Cambodian version, was adopted in December 2005, the same year and month as the $3^{\text {rd }}$ Education Strategic Plan (MoEYS, 2005b). This is not surprising given that the ESSP was created to compliment the objectives laid out in the $3^{\text {rd }}$ ESP. The Cambodian ESSP is very much the practical element of the education reform process. Basically, the purpose of the ESSP is to "outline how the policies and strategies laid out in the Education Strategic Plan (ESP) 20062010 will be put into practice” (MoEYS, 2005b, p. 1). This program aims to translate over-arching policy into manageable and measurable tasks.

In addition to these policies, in 2002 the Royal Government of Cambodia passed the Policy of Non-Formal Education (RGoC, 2002). In the Policy of Non-Formal Education the Royal Government states that non-formal education is as important as the formal education system. In addition, they feel that non-formal education is necessary within a global context as it aligns with the Education For All mandate, in that non-formal education leads to a lifelong learning environment. This is socially and culturally significant for a country 
such as Cambodia where there is a high illiteracy rate among adults and youths (RGoC, 2002).

In addition to the Policy of Non-Formal Education, the Ministry of Education, Youth and Sport also created and adopted a National Policy for Curriculum Development (2005-2009) (MoEYS, 2004) and a Child-Friendly School Policy (MoEYS, 2007). The former was adopted in December 2004 and the latter was adopted in December 2007. Each of these policies relate directly to the education reform agenda.

The policy analysis conducted for this study discovered several key themes emerging throughout all the documents under study. Within these themes, a variety of differences were found between the Cambodian national policy documents and the multinational policy directives. These differences are not always extreme. In actuality they are often quite subtle. Yet, this subtlety can speak volumes about the various perceptions about education and demonstrate the complexities involved in reforming education in a collaborative manner in a post-conflict nation. These themes will be discussed below.

\section{REFORM THEMES}

\section{The Marketization of Education}

One of the key aspects of a globalized economic system is a reliance on neoliberal ideals. A neo-liberal reform agenda involves a shift from a state-centred system to a market-driven social, political, and institutional system (Haque, 1999). The combination of globalization and neo-liberalism has created an environment where education has become a business with national and international partners. The policy documents analyzed in this study reflect a neo-liberal reform agenda, both on behalf of the multinational organizations and Cambodian government. This is due to the fact that one of the principal trends throughout the documents is the move toward the marketization of education.

The marketization of education has been a particular trend since the 1980's when neo-liberal ideals infiltrated national and international political structures leading to calls for a shift from "welfarism" to "new managerialism" (Gewirtz and Ball, 2000). This shift had a direct impact on education and education policy as the "economic imperative" of neo-liberalism came to dominate the educational agenda of national governments and multinational organizations (Tomlinson, 2001, p. 155). Beech (2009) points out that they become "new types of actors" who participate "in the 'business' of giving policy-oriented advice based on the transfer of 'solutions' from one context to another" (p. 344). In the case of Cambodia, the "new types of actors" in their policy making process include the World Bank and Asian Development Bank. Gewirtz and Ball (2000) hold that the shift to a business model in education entails a move from a "learner-needs" perspective to an "institutional-needs" perspective situated in the "paradoxical logic of market discipline" (p. 254). As shall be demonstrated, this shift is certainly clear within the multinational policy 
directives. However, the shift is more veiled in the Cambodian policy documents where there appear to be attempts to hold onto a learner-needs perspective.

Due to their emphasis on banking and finance, the multinational organizations policy-oriented advice emphasizes business-model reforms that focus on neo-liberal ideals such as efficiency, effectiveness, and accountability.

The recent policy directives of the World Bank indicate that efficiency, effectiveness and accountability have been issues in the reform agenda in Cambodia in the past. In fact, the policy directives tend to put the majority of the blame for the failure of earlier reform attempts on the Cambodian government due to their lack of good governance (World Bank, 2005b). The CAS notes that poor governance, which is defined by the World Bank through their Country Policy and Institutional Assessment parameters, in Cambodia is to blame for a reduced Bank Group effectiveness and the failure to achieve development outcomes in Cambodia (World Bank, 2005b). This belief was then used as a filter through which the World Bank decided which projects to fund. If a government is strongly committed to reforming their governance of a sector, then the World Bank and its partners would support a defined reform agenda with financial aid (World Bank, 2005b).

Therefore, at the highest level, the Cambodian Government is accountable for their governing practices. If they fail to meet World Bank standards for effectiveness, the IDA will utilize their right to "strategic selectivity" and cease funding basic programs and policy directives in the country.

In this environment of new managerialism, the purpose of schooling becomes about raising standards and student performance which are measured through the use of standardized tests (Gewirtz and Ball, 2000, p. 255). This is the mindset behind the implementation of the National Assessment System in Cambodia (NAS). The NAS becomes a tool of accountability impacting all levels of the education sector. It is another example of how globalization has led to multinational organizations "selling" policy directives from one context to another.

The ADB Cambodian policy directives also emphasize accountability, efficiency, and effectiveness. In these policy directives, the term costeffectiveness is very much connected with the activities conducted within the schools everyday. Of particular importance for the ADB is student performance and how it relates to the cost of daily operations. Specifically, they are very concerned with the high repetition rates for students. As the ESDP II states, "repetition rates remained high resulting in significant costs for the Government and poor families" (2004a, p. 28). The repetition rates are particularly high in rural areas. The ADB reports a progression rate of just $67 \%$ for grade 1 students (ADB, 2004a). One of the strategies proposed to help alleviate the repetition rate is to introduce "cost-effective remedial programs" (ADB, 2004a). These 
programs are designed to help students progress to the next grade level in a shortened time period. In terms of the program targets, the ADB lists a reduction in repetition rates as a key indicator for improved quality and internal efficiency. The target is to reduce the repetition rate from $10 \%$ in 2003 to $1 \%$ in 2008 for students in grade 1 to 3 (ADB, 2004a, p. 33), although current reports indicate that the repetition rates still remained around 10\% in 2008 (World Bank, 2008). To reduce repetition rates, it would be much more cost-effective to have these students complete a short remedial program rather than have them repeat an entire year of school at the same grade level. Yet, doing a short remedial program for the primary grades is quite complex given that the development of basic skills such as reading and writing is a long-term process. Therefore, these remedial programs may be cost-effective but their educational effectiveness is questionable. In addition, this program shows how neo-liberal education reforms are moving education away from a learners-needs agenda to an institutional-needs agenda. A short remedial program is certainly more beneficial for the institution rather than the learner. In sum, the ADB believes that the repetition rates of students need to be addressed due to the perception that it was a sign of inefficiency and overall ineffectiveness.

The Cambodian government policies also indicate a focus on effectiveness through good governance, efficiency, and accountability. This can be seen in one of the key collaborative strategy papers that influenced the creation and adoption of the $3^{\text {rd }}$ ESP and education reform in general, the Royal Government of Cambodia's (RGoC) Rectangular Strategy Policy. According to the Royal Government, the Rectangular Strategy is a key element used to support the implementation of their political platform (MoEYS, 2005a). The strategy consists of a series of four interlocking rectangles. What is particularly interesting is that at the centre of the rectangles is "good governance" which the Royal Government perceives to be the core of their agenda, a key element of neo-liberal ideals. However, what makes this particularly interesting is that the multinational financial agencies insist on an improved governing structure to maintain their funding programs. Therefore, it seems that the Cambodian government has internalized this insistence on improved governance and made it the core of their agenda. This demonstrates how global initiatives get taken up within a national context.

One of the groups most affected by this drive for effectiveness through good governance, efficiency, and accountability are teachers working in the Cambodian education sector. The assumption with the multinational financial agencies and Royal Government is that a cost-effective, efficient, and properly governed system ensures educational quality. In the recent past in Cambodia, teachers have been poorly trained and quite scarce. The scarcity is a result of the Khmer Rouge and their direct targeting of educated individuals (Ayres, 2000). Teachers have also been very poorly paid and often expected informal payments from parents for their services to supplement their official income. 
Although the Royal Government recognizes this as a common practice in the education sector, the multinational financial organizations have viewed it as an example of corruption and bribery (ADB, 2004a; WB, 2005a). They have also seen informal teacher payments as contrary to their pro-poor agenda as they see it as a major barrier for poor individuals seeking to enter the formal education sector. However, in this assessment they fail to acknowledge that the teachers themselves also fit into that "poor" category. However, the multinational financial organizations have demanded that informal payments be discouraged and eventually outlawed (ADB, 2004a; WB, 2005a). They are not costeffective.

In order to offset the loss of the informal payments as part of teacher's incomes, the MoEYS has come up with a plan to ensure quality teaching practices within a pro-poor system. In the $3^{\text {rd }}$ ESP and ESSP, they are have advocated the implementation of a strict staff performance appraisal system with appropriate reporting procedures (MoEYS, 2005a; MoEYS, 2005b).

In addition to this, is the movement to tie teacher salaries to their performance appraisals, an idea promoted by the ADB (2004a). According to the $3^{\text {rd }}$ ESP, "The elimination of informal contributions, offset by improved performance-based teacher salaries and allowances is designed to create a climate within which Government and communities are prepared to hold school directors and teaching and non-teaching staff accountable” (MoEYS, 2005a, p. 19). This new system of performance based salary is intended to create a "more effective institutional framework for pro-poor access as well as quality improvement" (MoEYS, 2005a, p. 19).

The attempt to eradicate the traditional payment system within the Cambodian education sector is an example of how "policy-oriented advice" from the international community gets taken up within a national context (Beech, 2009). In this case, multinational financial organizations presented a "solution" to a perceived "problem". The informal payments to teachers were seen as a problem internationally because they were neither efficient nor effective in promoting the development of the economic structure of Cambodia. They were also very difficult to account for as they were outside of the official monitoring system. As a result, they ran counter to the policy-oriented advice given to the Royal Government of Cambodia by the multinational financial organizations and were addressed in the Cambodian national policy documents. Ball (1992) explains that in situations such as this, where a poor country is dependent on international financial assistance, "attempts are made to displace issues of moral and cultural identity with the imperatives of administrative efficacy” (p. 154). Informal teacher payments were part of Cambodian cultural identity, yet within the Cambodian policies themselves they were discouraged in favour of effectiveness and efficiency.

\section{Partnerships}


A second theme found throughout the policy documents and directives discussed in this paper is the use of partnerships. However the understanding of the roles, makeup and positions of these partnerships varies between organizations. This is in line with Buenfil Burgos' (2004) notion that the term partnership has become a "floating signifier" within educational policies and reform (p. 55). Specifically, he states that "the meaning of this word changes in each particular moment and site of enunciation" despite the appearance in educational policies that there is a universal, natural value attached to the term (2004, p. 55).

In their policy directives for Cambodian education reform, the World Bank and Asian Development Bank tend to emphasize the importance of multinational-national and private partnerships. The World Bank sees the partnering of multinational agencies involved in education reform in Cambodia as providing an additional benefit to the relationship between the Royal Cambodian Government and the financial community. According to the CAS, the partnership of financial agencies "has also helped to ensure greater coherence and consistency in the messages that the four donors (World Bank, ADB, DFID, UNDAF) (and by extension the financial community) send the Government - and other Cambodian stakeholders - about their objectives and requirements" (World Bank, 2005b, p. 1). A partnership between the major multinational and national financial organizations helps to send a clear message to the Cambodian government about what type of conditions and expectations come along with the financial assistance. The partnership also limits the Cambodian government's ability to seek financial assistance elsewhere if they are unhappy with the conditions of one financial agency.

The promotion of the use of partnership in the multinational policy directives goes alongside with the discussions around increasing efficiency within Cambodian society in general and the education sector in particular. For example, the CAS talks about how a partnership among community members and financial agents helped to reduce the time and effort required to achieve the goals of a past project, while the ESSP talks about how partnerships promote harmonization and help avoid overlapping or duplication in reform efforts (World Bank, 2005a; 2005b). Therefore, the whole idea of using partnerships in development efforts and education reform in Cambodia is very much tied into the notion of creating an efficient system.

The ADB views partnership with the private sector as the key to successful education reform in Cambodia. Education is an expensive endeavour and the ADB is the largest financier. Therefore, they seem to be concerned with passing some of the cost off to other groups. Given their partnership with the other multinational organizations they are aware of how much more can come from the multinational community and the same can be said for their knowledge of the amount available from the Royal Cambodian Government. Therefore, the other key source of financing is the private sector. It is here that the greatest increase in financial investment can come. One of the recommendations from 
the ADB at the end of the last Country Strategy Program (2004) was for the Bank to work at improving aid coordination and mobilizing additional resources in Cambodia (ADB, 2004b). It seems clear after reading through the ESDP II that those additional resources are to come from the private sector, specifically the private sector of member states.

The Cambodian government also sees value in partnership. However, their perception is that partnership is part of a progression toward independence. The $3^{\text {rd }}$ ESP makes the distinction between donorship and partnership (MoEYS, 2005a). Donorship implies the process of just giving money with no other influence on how that money is spent. In contrast, partnership implies influence beyond the giving of money. Partnership indicates a working relationship used to develop institutions and government ownership. It is clear that external financial agencies have an active role in Cambodian social and education reform and development. The statement from the $3^{\text {rd }}$ ESP also lays out the Royal Government's ultimate goal is to move away from a dependence on partnership to total government ownership (MoEYS, 2005a). However, no time frame is ever given for the end of partnerships and government independence.

In working toward this independence the Royal Government sees value in partnering with non-governmental organizations (NGOs), particularly in the non-formal education arena. The Royal Government has put a real emphasis on the expansion of the non-formal education sector, yet there was little allocated funding for it in the multinational policy directives. The multinational organizations are acutely interested in the formal system of education but are wary to invest their money in a non-formal sector. As a result, the Royal Government has had to look elsewhere for assistance in developing this sector. In this venture, the non-government organizations can play a key role. The main reason for this appears to be the NGOs placement in highly disadvantaged communities. The non-formal education sector is generally intended to target poorer communities and individuals who are unable to attend a formal education institution due to their economic and/or social situation. Therefore, utilizing NGOs that are already in place in many of the poorer communities could be very efficient for a government struggling with the financial realities of education reform. In addition, the Royal Government acknowledges that NGOs are already at the forefront of piloting and implementing non-formal education program (RGoC, 2002).

The emphasis on partnership with NGOs that is consistent through the Cambodian government documents seems to serve two key purposes. The first is the acknowledgement on the Royal Government's behalf that they will not be able to meet the education reform goals by 2015 through multinational financial assistance to the formal sector alone. Partnership between financial organizations and the government is important but not enough. The NGOs are a very acceptable partner in that they are already working in the non-formal 
education sector (a priority program in the ESSP), a sector other financial organizations seem to want little to do with.

In addition, another possible reason for the Royal Government's leaning toward NGO partnership could have to do with their view that partnership is a step in the progression toward government ownership. The ambiguous nature of the term partnership often has political purposes. NGOs are by definition non-governmental and therefore they have no governmental ties and aspirations. If the Royal Government truly wants ownership over the education sector, all other governmental ties will have to be cut. This cannot be done while large multinational financial organizations are partnering to develop and operate the sector and develop and amend national education policy. Therefore, the tendency to venture toward NGO partnership, particularly in the non-formal sector - a sector which the Royal Government sees as more socially and culturally appropriate for Cambodia, can be seen as an attempt to move beyond partnership to the government ownership advocated in the $3^{\text {rd }}$ ESP.

So as can be seen in this discussion, the term partnership can have multiple uses and understandings within the educational reform discourse. The emphasis on partnership is attached to changing patterns of governing, particularly in a post-conflict developing nation such as Cambodia. According to Buenfil Burgos (2004), the "floating nature" of the term leads to a double purpose for the implementation of partnerships. He states that partnership can be "both the road to salvation - to democracy and national progress, equity and control over corruption, the civil society involvement in education, and so onand also the road to imperialist exploitation-that is, the withdrawal of government responsibility over public education” (p. 73). The Cambodian government hopes for the use of partnerships to be a temporary stage of national progress, their "salvation" for development and yet the multinational organization policy directives give no indication that this will be part of a progress. In fact, their "policy-oriented advice" indicates an increase in imperialist control over the education sector as the marketization of education advocates a withdrawal of government responsibility over public education.

\section{Purpose of Education}

A third theme that emerged during the course of the policy analysis in this study was that there were varying understandings around the purposes of education in Cambodia. Specifically, there is a variation among groups as to how much emphasis should be placed on the economic purposes of education and the social/cultural purposes of education. On one hand, the multinational organizations hold the belief that the "rationale for learning is openly technicalrationalist, economic and reductionist, and provides no reasons why learning might be a good other than its economic usefulness" (Bottery, 2000, p. 19). A key sign of economic "backwardness" is the levels of poverty among a people. Therefore, the multinational organizations based their education reforms around 
the concept of poverty reduction (Beech, 2009). Poverty can not lead to prosperity and education is the key to eradicating poverty in the view of the multinational organizations (ADB, 2004a; WB, 2005a).

In Cambodia, poverty remains a major issue. At the start of the World Bank's ESSP in August of 2005, 35-40\% of the population lived below the poverty line (World Bank, 2005a). Out of that number, 15-20\% lived in extreme poverty. In the more recent 2008 Human Development Index, Cambodia is ranked $136^{\text {th }}$ out of 179 countries.

According to the World Bank, there is a great deal of evidence to support the notion that reforms in the education sector can lead to improvements in living standards, economic growth, public health, and most importantly, poverty alleviation (World Bank, 2005a). The World Bank holds that education reforms that take place in a developing nation must be aligned with the development of the nation's economic structures (World Bank, 1995).

In Cambodia the perception is that a strong education system will lead to more skilled workers who will diversify the Cambodian economy and move it away from a dependence on subsistence agriculture (World Bank, 2005a; World Bank, 2005b). Agricultural workers are referred to as the "low human resource base” in the multinational policy directives (World Bank, 2005a, p. 58). For a successful economy, education in Cambodia must work toward creating a high level human resource base.

In terms of addressing poverty, the ADB's EDSP II is designed to reform education in Cambodia into a market-responsive sector that allows for an increased level of educational attainment in the workforce and increased household income (ADB, 2004a). Like the World Bank, the ADB focuses on reforming the agricultural workforce (ADB, 2004a). They conclude that most of the individuals in agriculture have little to no education and as such a connection can be drawn between education and income. As the ADB states, "incidence of higher levels of poverty correlates strongly with levels of participation in education and training and geographical variations in provision of basic education and skills training" (2004a, p. 1). For the ADB, education is about skill attainment. Those skills that are most valued are those that translate to employability and this is the purpose of education.

For their part, the Cambodian government seems to hold with the belief that a monitored, efficient system is good for Cambodia. They acknowledge that corruption has been an issue in the past and know that reform is necessary. However, the Cambodian government also has a real tendency to emphasize a cultural, social, and moral element to education. Perhaps the greatest discrepancy between the multinational policy documents and the Cambodian national education policies is that there is much less of an economic emphasis in the Cambodian documents.

The $3^{\text {rd }}$ Education Strategic Plan lays out its overall vision for education reform in Cambodia. The MoEYS sees its mission as "leading, 
managing and developing education, youth and sport sector in Cambodia in responding to the socio-economic and cultural development needs and the reality of globalization" (2005a, p.1). These statements are very interesting in that the MoEYS recognizes the significance of globalization and sees it as their mission to help Cambodian citizens develop economically and culturally within a new global system. Yet more importantly, the $3^{\text {rd }}$ ESP holds that a major purpose of education is to develop a holistic individual able to operate in a proud national and international environment. This is reflected in other national policy documents as well.

According to the Policy for Curriculum Development (2004), the aim of curriculum is to fully develop "the talents and capacities of all students in order that they become able people, with parallel and balanced intellectual, spiritual, mental and physical growth and development” (MoEYS, 2004, p. 1). Nowhere in this statement does it make mention that the goal of the curriculum is to produce an economically viable individual. In addition, the Child Friendly Schools Policy also emphasizes the social, cultural, and moral development of Cambodian youth. This policy also stresses the importance of generating the four compassions, which are: metha (empathy); karuna (loving kindness); obeka (equanimity); muktetha (feeling arising from seeing reduction in suffering of others). These are grounded in the Buddhist faith of the country (MoEYS, 2007). The spiritual tone present in the Cambodian education reform agenda is much more in line with the culture of the country.

In stating these purposes of education, the Cambodian government has shown the desire and ability to resist and reinterpret global educational discourses that are put forward by the multinational financial institutions (Beech, 2009). This variance in understanding around the purpose of education between the Cambodian government and multinational organizations is also indicative of different visions for the re-development of the country. For the Cambodian government, a post-conflict government, there is still a great deal of emphasis on the social and cultural elements of education. It is important for them to develop and instil a sense of national pride and citizenship in a wary populace after decades of social unrest and political instability. In a sense, education becomes a tool of self-preservation for the Cambodian state. Yet, for the multinational financial organizations, economic matters are their primary concern. They are in the money business and getting re-paid and the maintaining of a global capitalist system is the purpose of their existence. Yet, this does not mean that the Cambodian government sees no economic purpose for education. They certainly do, but they reinterpret this purpose and combine it with social and cultural purposes to create a uniquely Cambodian system through all their national education policies. 


\section{CONCLUSIONS}

The policy documents and directives discussed in this paper present a compelling view of an education system in transition caught between global demands and national needs. There are many overlapping themes but also many distinct variations between the documents of each group involved in the education reforms in Cambodia. The presence of the similarities between the various documents and directives indicate that international agendas have impacted the development of Cambodian national education policy. However, the policies also demonstrate how the Royal Government of Cambodia has been able to resist complete acceptance of the "policy oriented advice" of the major financial providers to maintain a sense of national identity and purpose within the education reform agenda. Education reform in Cambodia is a prime example of the conflict and complementarity that emerges when national and international agendas struggle to become one. 


\section{References}

Asian Development Bank (ADB). (2008). Country Operations Business Plan: Cambodia 20082010. Manilla, Philippines: ADB.

Asian Development Bank (ADB). (2004a). Second Education Sector Development Program (ESDP II). Manilla, Philippines: ADB.

Asian Development Bank (ADB). (2004b). Country Strategy Program. Manilla, Philippines: ADB. Ayres, D. (2000). Anatomy of a crisis: Education, development, and the state in Cambodia, 19531998. Honolulu, HI, USA: University of Hawaii Press.

Ball, S. (1992). Management as moral technology: A Luddite analysis. In S. J. Ball (Ed.), Foucault and education: Disciplines and knowledge. New York, NY, USA: Routledge, pp. 153166.

Beech, J. (2009). Who is strolling through the global garden? International agencies and educational transfer. In R. Cowen \& A. Kazamias (Eds.), International Handbook of Comparative Education. New York, NY, USA: Springer, pp. 341-357.

Bottery, M. (2000). Education Policy and Ethics. London, UK: Continuum.

Buenfil Burgos, R. (2004). Partnership as a floating and empty signifier within educational policies: The Mexican case. In B. Franklin, M. Bloch, \& T. Popkewitz (Eds.), Educational partnerships and the state: The paradoxes of governing schools, children and families. New York, NY, USA: Palgrave Macmillan, pp. 55-79.

Gerwirtz, S. \& Ball, S. (2000). From 'Welfarism' to 'New Managerialism': Shifting discourses of school headship in the education marketplace. Discourse: Studies in the cultural politics of education, 21(3), 253-268.

Haque, M. (1999). The fate of sustainable development of neo-liberal regimes in developing countries. International Political Science Review, 20(2), 197-218.

Ministry of Education, Youth, and Sport (MoEYS). (2007). Child friendly school policy. Phnom Penh, Cambodia: Ministry of Education, Youth, and Sport.

Ministry of Education, Youth, and Sport (MoEYS). (2005a). Education Strategic Plan 2006-2010. Phnom Penh Cambodia: Ministry of Education, Youth, and Sport.

Ministry of Education, Youth, and Sport (MoEYS). (2005b). Education Sector Support Program 2006-2010. Phnom Penh Cambodia: Ministry of Education, Youth, and Sport.

Ministry of Education, Youth, and Sport (MoEYS). (2004). Policy for curriculum development 2005-2009. Phnom Penh Cambodia: Ministry of Education, Youth, and Sport.

Ministry of Education, Youth, and Sport (MoEYS). (2003). Education for all national plan 20032015. Phnom Penh Cambodia: Ministry of Education, Youth, and Sport.

Moghadam, V. (2005). Globalizing women: Transnational feminist networks. Baltimore, MD, USA: John Hopkins University Press.

Royal Government of Cambodia (RGoC). (2002). National Policy of Non-Formal Education. Phnom Penh Cambodia: Royal Government of Cambodia.

Tomlinson, S. (2001). Education in a post-welfare society. Buckingham: Open University Press.

World Bank (2008). Developing knowledge economy strategies to improve competitiveness: Team Cambodia. Washington, DC, USA: World Bank.

World Bank (2005a). Cambodia: Education Sector Support Program. Washington, DC, USA: World Bank.

World Bank (2005b). Country assistance strategy for the Kingdom of Cambodia. Washington, DC, USA: World Bank.

World Bank (1995). Priorities and strategies for education: A World Bank sector review. Washington, DC, USA: World Bank.

Kelly Crowley-Thorogood is a $\mathrm{PhD}$ candidate in the Faculty of Education at the University of Western Ontario. She can be reached at kcrowley@uwo.ca. 